\title{
Pengaruh Penerapan Booklet Kunjungan pada Akseptor KB Suntik 3 Bulan terhadap Pengetahuan, Sikap, dan Ketepatan Waktu Kunjungan Ulang
}

\author{
Nurrasyidah, ${ }^{1}$ Benny H. Purwara, ${ }^{2}$ Herry Herman, ${ }^{3}$ Farid Husin, ${ }^{4}$ Tono Djuwantono, ${ }^{5}$ Irvan Afriandi ${ }^{6}$ \\ Hadyana Sukandar ${ }^{7}$ \\ ${ }^{1}$ Mahasiswa Program Studi Magister Kebidanan Fakultas Kedokteran Universitas Padjadjaran \\ ${ }^{2,5}$ Departemen Obstetri dan Ginekologi Fakultas Kedokteran Universitas Padjadjaran \\ ${ }^{3}$ Departemen Orthopaedi Fakultas Kedokteran Universitas Padjadjaran \\ ${ }^{4,7}$ Departemen Epidemiologi dan BiostatistikFakultas Kedokteran Universitas Padjadjaran \\ ${ }^{6}$ Departemen Ilmu Kesehatan Masyarakat Fakultas Kedokteran Universitas Padjadjaran
}

\begin{abstract}
Abstrak
Tingkat keberlangsungan penggunaan alat kontrasepsi/ KB suntik 3 bulan semakin rendah dibandingkan kontrasepsi lain. Booklet kunjungan merupakan media yang digunakan untuk menyampaikan informasi tentang $\mathrm{KB}$ suntik 3 bulan yang bertujuan untuk meningkatkan keberlangsungan penggunaan secara efektif. Penelitian ini bertujuan untuk menganalisis perbedaan peningkatan pengetahuan, sikap, dan pengaruhnya terhadap ketepatan waktu kunjungan ulang.Penelitian ini merupakan penelitian analitik dengan desain quasi eksperiment dengan non equivalent pre-test post-test control group design, dengan jumlah sampel $31 \mathrm{orang} / \mathrm{kelompok}$ dengan teknik consecutive samplingdi Puskesmas Kejuruan Muda Aceh Tamiang pada periode 3 Juli-28 Oktober 2015. Data dianalisis dengan UjiT tidak berpasangan atau ujiMann-Whitney(jika data tidak berdistribusi normal) untuk menguji perbedaan peningkatan pengetahuandan sikap,sedangkan uji Chi Square untuk menguji pengaruh penerapan booklet kunjungan terhadap ketepatan waktu kunjungan ulang. Instrument yang digunakan untuk mengukur pengetahuan dan sikap adalah kuesioner. Sedangkan ketepatan waktu kunjungan ulang dilakukan pengamatan melalui catatan kunjungan ulang yang dimiliki akseptor.Hasil analisis diperoleh persentase peningkatan pengetahuan pada kelompok perlakuan sebesar 33,3\% sedangkan kelompok kontrol sebesar 25\%. Pada sikap diperoleh persentase peningkatan kelompok perlakuan dan kelompok kontrol sebesar 0\%.Perbedaan peningkatan pengetahuan dan sikap secara statistik tidak bermakna $(\mathrm{p}>0,05)$. Penerapan bookletkunjungan berpengaruh terhadap ketepatan waktu kunjungan ulang $(\mathrm{p}<0,05)$.Bookletkunjunganmerupakan media pendidikan kesehatan yang tidak berbeda dengan informasi yang disampaikan secara lisan dalam meningkatkan pengetahuan dan sikap, namun berpengaruh terhadap ketepatan waktu kunjungan ulang akseptor KB suntik 3 bulan. Dengan penerapan yang maksimal akan lebih meningkatkan pengetahuan, dan sikap serta lebih menumbuhkan kesadaran tentang pentingnya penggunaan KB suntik 3 bulan yang berkesinambungan.
\end{abstract}

Kata kunci: Booklet, kunjungan ulang, pengetahuan, sikap, suntik KB 3 Bulan.

Korespondensi :Jl. Rantau No. 41 Bukit Tempurung Kota Kuala Simpang Kabupaten Aceh Tamiang, Hp 082364114222, e-mailnoorsyidaa@yahoo.co.id 


\title{
The Influence of Three-Months Injectable Contraceptive's Booklet For Acceptor Towards Knowledge, Attitude, and Timeliness of Contraceptive Reinjection
}

\begin{abstract}
The continuity rate of three months injection used is lower than other contraceptives. This is caused by not timely acceptor in reinjection. Three-months injectable contraceptive's booklet is the media used to give information about three month injections that aim to improve the sustainability of effective use. This research aimed to analyze the Different of improvement for knowledge, attitudes, and the influence it for timeliness of contraceptive reinjection to acceptors with three-months injectable contraceptive's booklet and acceptors without three-months injectable contraceptive's booklet. This research is an analytical study with quasi experiment design with non-equivalent pretest posttest control group design. We recruited 31 people/groups with consecutive sampling technique at Kejuruan Muda's Public Health Centre Aceh Tamiang's district for period July $3^{\text {rd }}$-October $28^{\text {th }}$, 2015. The data were analyzed with unpaired $\mathrm{T}$ test or Mann-Whitney test (if the distribution of data is not normal) for measuring different of improvement for knowledge and attitude and unpaired t test for measuring different of improvement in attitude. Chi square test for measuring the influence of three-months injectable contraceptive's booklet for timeliness of contraceptive reinjection. The instrument used in this study was a questionnaire on knowledge and attitudes. The timeliness of contraceptive reinjection conducted with observations by acceptor's card. The result of analysis was found that the percentage increase in knowledge for treatment group is $33,3 \%$, for the control group is $25 \%$. The percentage increase in attitude for treatment and control group is $0 \%$. The difference level on knowledge, attitude on the treatment and control group shown no sigificant difference $(\mathrm{p}>0.05)$. Three-months injectable contraceptive's bookletwas affect the timeliness of contraceptive reinjection $(p<0.05)$. Three-months injectable contraceptive's booklet is as health educational media were contains no difference with information given orally in order to increase konowledge and attitude level, but it has significant influence towardsthe timeliness of contraceptive reinjection. By optimizing the implementation will increase the level of knowledge, attitude and creating more alert about the continuous rate of using injections of three-months injectable contraceptive.
\end{abstract}

Keywords:Booklet, reinjection, knowledge, attitude, three-months injectioncontraceptive.

\section{Pendahuluan}

Setiap tahun sekitar 20.000 perempuan di Indonesia meninggal akibat komplikasi saat melahirkan. ${ }^{1}$ Menurut perkiraan WHO (World Health Organization) sekitar 15-20\% ibu hamil, baik di negara majumaupun berkembang akan mengalami risikotinggi dan/atau komplikasi. ${ }^{2}$ Tahun 1991 AKI (Angka Kematian Ibu)sebesar 390 menurun menjadi 228/ 100.000 kelahiran hidup pada tahun 2007. Namun, pada tahun 2012 AKI meningkat kembali menjadi 359/ 100.000 kelahiran hidup. MDGs (Millenium Development Goals) menargetkanpada tahun 2015akanmenurunkan AKI hingga 102/ 100.000 kelahiran hidup. Berdasarkan Laporan Kesehatan Negara di Inggris menunjukkan bahwa terdapat peningkatan jumlah kehamilan yang tidak diinginkan, sehingga hal ini penting untuk melakukan perbaikan akses pelayanan Keluarga Berencana (KB) untuk semua wanita, terutama wanita yang masih muda. ${ }^{3}$

Tujuan kelima MDGs difokuskan pada kesehatan ibu untuk menurunkan kematian.Salah satu upaya yang dilakukan adalah dengan memperkuat programKB melalui peningkatan akses dan kualitas pelayanan KB dan kesehatan reproduksi serta peningkatan advokasi, komunikasi, informasi, dan edukasi (KIE) KB. Peningkatan pemahaman kesadaran tentang KB dan kesehatan reproduksi pada pasangan usia subur (PUS) mampu merencanakan kehamilan dengan baik sehingga kesehatan dan kesejahteraan ibu dan anak dapat ditingkatkan. ${ }^{2}$

Suntik progesteron tiga bulan dan dua bulan merupakan metode kontrasepsi yang paling 
efektif.Namun, dalam praktiknya efetivitas metode ini berkurang. Keberlangsungan pengguna dalam menggunakan metode ini lebih rendah dibandingkan dengan metode kontrasepsi lain. Hal ini terbukti oleh adanya praktik kunjungan ulang yang terlambat atau tidak tepat waktu yang dilakukan pengguna. ${ }^{4-7}$

Beberapa alasan akseptorterlambat melakukan kunjungan ulangdiantaranya seperti adanya pertentanganprioritas(misalnya ketidakmampuan untukabsendaripekerjaanatau sekolah, ketidaknyamanan dari waktu kembali yang ditentukan oleh klinik, tidak ada waktu padatanggal yang telah dijadwalkan atau ada suatu acara kumpul keluarga), lupa akan janji untuk suntik ulang, tidak memiliki sumber daya(transportasi dankeuangan), sudah lewat daritanggal yang dijadwalkan, seksualitas tidakaktif padawaktuyang dijadwalkan untuk suntik kembali, mengikuti masa menstruasiatauberistirahatdariber-KB, danbahkan tanpa suatualasan. ${ }^{8}$

Berdasarkan hasil penelitian lain diketahui bahwa sumberinformasi tentangDMPApersentase terbesar diperoleh dariteman(42\%) danpenyedia layanan kesehatan(37\%). ${ }^{9}$ Temanbukan hanya merupakan sumber awal yang memberikan informasi tentangdepo-provera, tetapi juga sebagaisumberinformasi yang tidak akurat,yangmemberikan kontribusi terhadapkeputusanperempuanuntuk

menghentikan penggunaan. ${ }^{10}$ Metode DMPA memilikicitra publikyang sangat buruk, yang secara alamimembuatpengguna cemas dantunduk padainformasi yang salahdari sumberinformasiburukataubias. ${ }^{11}$

Cakupan pelayanan KB yang diperoleh dari Dinas Kesehatan Kabupaten Aceh Tamiang berdasarkan angka kejadian Drop Out KB suntik tahun 2013 yakni 8,49\% (957 kasus dari 11.272 pengguna). Angka kegagalan KB tahun 2013 berjumlah 124 kasus dan tahun 2014 (Januari-Juli) terdapat 143 kasus. Berdasarkan studi awal yang dilakukan oleh peneliti di Puskesmas Kecamatan Rantau di Kabupaten Aceh Tamiang pada akseptor KB suntik 3 bulan yang hanya diberikan informasi singkat dan kartu KB sebagai pengingat suntik ulang menunjukkan $89,47 \%$ (17 dari 19 pengguna) melakukan kunjungan ulang tidak tepat waktu. Berdasarkan data Dinas Kesehatan Kabupaten Aceh Tamiang tahun 2013, Puskesmas Kecamatan Kejuruan Muda merupakan kecamatan yang memiliki peserta KB suntik tertinggi yaitu sebesar 1962 pengguna.

Berdasarkan permasalahan di atas, sangat pentingmenyediakan selebaran informasi yang mudah dipahami, informasi akuratyang diberikan kepada pengguna,sehingga informasiyang biasdantidak akuratdapatdiabaikan. Menurut WHO, salah satu strategi perubahan perilaku dapat dilakukan melalui pemberian informasi yang bertujuan untuk meningkatkan pengetahuan. ${ }^{12}$ Pemberian informasi merupakan salah satu strategi untuk mengubah perilaku. Penggunaan indera mata paling banyak menyalurkan pengetahuan ke otak $\pm 75-87 \%$ dalam menyerap informasi. ${ }^{13}$ Media visual dapat membantu kegiatan promosi kesehatan salah satu diantaranya dengan menggunakan media cetak. ${ }^{14}$

Bookletkunjungan KB suntik 3 bulan merupakan salah satu media cetak yang berisi informasi yang memuat tulisan dan gambar dalam bentuk buku yang dapat membantu tenaga kesehatan menyampaikan pesan kesehatan dalam upaya meningkatkan pengetahuan,sikap, dan daya ingat akseptor akan jadwal suntik ulang serta menepis seluruh informasi yang tidak akurat. ${ }^{14}$ Berdasarkan uraian di atas, tujuan penelitian ini adalah mengukur pengaruh penerapan booklet kunjungan KB suntik 3 bulan terhadap pengetahuan, sikap, dan ketepatan waktu kunjungan ulang akseptor KB suntik 3 bulan.

\section{Metode}

Penelitian inimenggunakan rancangan quasi eksperimendengan non equivalent pre-test posttest control group design.Dilakukan dengan menerapkan booklet kunjungan pada akseptor KB suntik 3 bulan. Variabel terikat adalah pengetahuan, sikap, dan ketepatan waktu kunjungan ulang. Variabel perancu adalah pendidikan, pendapatan, paritas, dan transportasi.

Subjek pada penelitian ini adalah akseptor KB suntik 3 bulan di wilayah Puskesmas Kejuruan Muda Aceh Tamiang.Sampel penelitian ini berjumlah 31 orang/kelompok. Kriteria inklusi: akseptor aktif KB suntik 3 bulan yang melakukan kunjungan ulang, bersedia mengikuti penelitian ini sesuai dengan tata kerja (informed consent), bisa membaca dan menulis, dan bertempat tinggal di wilayah puskesmas setempat, serta terjangkau oleh peneliti. Kriteria eksklusi: tuli dan kader atau tenaga kesehatan. Instrument yang digunakan untuk mengukur 
pengetahuan dan sikap adalah kuesioner, sedangkan untuk mengukur ketepatan waktu kunjungan ulang dilakukan pengamatan pada catatan kunjungan yang dimiliki responden.Setelah data terkumpul dilakukan pengolahan editing, coding, transferring, dan tabulating. Tahap akhir data akan dianalisis menggunakan program SPSS. Penelitian akan dilaksanakan pada 3 Juli s/d 28 Oktober 2015.

\section{Hasil}

Tabel 1.Karakteristik Responden pada Kedua Kelompok Penelitian di Puskesmas Kejuruan Muda

\begin{tabular}{|c|c|c|c|c|}
\hline \multirow{2}{*}{$\begin{array}{l}\text { Karakteristik } \\
\text { Responden }\end{array}$} & \multicolumn{2}{|c|}{ Kelompok } & & \multirow{2}{*}{ Nilai $\left.p^{*}\right)$} \\
\hline & $\begin{array}{c}\text { Perlakuan } \\
(\mathrm{n}=\mathbf{3 1})\end{array}$ & $\begin{array}{c}\text { Kontrol } \\
(\mathbf{n}=31)\end{array}$ & & \\
\hline Pendidikan: & & & & 0,082 \\
\hline SD/SMP/Sederajat & 20 & 26 & & \\
\hline SMU/Sederajat & 11 & 5 & & \\
\hline \multicolumn{5}{|l|}{ Pendapatan: } \\
\hline$\geq \mathrm{UMR}$ & 9 & 5 & & 0,224 \\
\hline$<$ UMR & 22 & 26 & & \\
\hline \multicolumn{5}{|l|}{ Paritas: } \\
\hline 1 & 5 & 7 & $0,070^{* *}$ & \\
\hline $2-4$ & 25 & 18 & & \\
\hline$>4$ & 1 & 6 & & \\
\hline \multicolumn{5}{|l|}{ Transportasi } \\
\hline Berjalan kaki & 10 & 15 & & 0,196 \\
\hline Sarana transportasi & 21 & 16 & & \\
\hline
\end{tabular}

Berdasarkan hasil analisis menunjukkan kesetaraan $(\mathrm{p}>0,05)$ sehingga layak diperbandingkan

Tabel 2. Perbandingan Skor Pengetahuan Akseptor Tentang KB Suntik 3 Bulan pada Kedua Kelompok Penelitian Sebelum dan Sesudah Perlakuan

\begin{tabular}{llccr}
\hline \multirow{2}{*}{ Pengetahuan } & & \multicolumn{2}{c}{ Kelompok } & \multirow{2}{*}{ Nilai p* } \\
\cline { 3 - 4 } & & Perlakuan(n=31) & Kontrol(n=31) & 0,322 \\
\hline Pre-test & Median & 50 & 50 & \\
\multirow{2}{*}{ Post-test } & Rentang & $12,5-100$ & $12,5-100$ & 0,119 \\
\multirow{2}{*}{$\%$ Peningkatan } & Median & 75 & 62,5 & \multirow{2}{*}{0,933} \\
& Rentang & $37,5-100$ & $25-100$ & \\
\hline & Median & 33,3 & 25 & \\
\hline
\end{tabular}

Keterangan: ${ }^{*}$ ) Uji Mann-Whitney

Hasil analisis perbedaan pengetahuan kedua kelompok pada sebelum dan sesudah perlakuan tidak bermakna $(\mathrm{p}>0,05)$. 
Tabel 3. Perbandingan Skor Sikap Akseptor KB Suntik 3 Bulan pada Kedua Kelompok Penelitian Sebelum dan Sesudah Perlakuan

\begin{tabular}{|c|c|c|c|c|}
\hline \multirow{2}{*}{ Sikap } & & \multicolumn{2}{|c|}{ Kelompok } & \multirow[b]{2}{*}{ Nilai $p$} \\
\hline & & $\operatorname{Perlakuan}(\mathrm{n}=31)$ & $\operatorname{Kontrol}(n=31)$ & \\
\hline Pre-test & $\begin{array}{l}\text { Median } \\
\text { Rentang }\end{array}$ & $75 \quad$ $47,5-92,5$ & $42,5-95$ & $0,388^{*}$ \\
\hline Post-test & $\begin{array}{l}\text { Median } \\
\text { Rentang }\end{array}$ & $\begin{array}{ll}77,5 & \\
& 65-95\end{array}$ & $\begin{array}{ll}77,5 & \\
& 40-95\end{array}$ & $0,108^{* *}$ \\
\hline$\%$ Peningkatan & $\begin{array}{l}\text { Median } \\
\text { Rentang }\end{array}$ & $\begin{array}{c}0 \\
-16,7-75\end{array}$ & $\begin{array}{c}0 \\
-54,3-47,1\end{array}$ & $0,251^{*}$ \\
\hline
\end{tabular}

Keterangan: ${ }^{*}$ ) UjiMann-Whitney ${ }^{* *}$ ) Uji T Tidak berpasangan

Begitu pula pada sikap akseptor menunjukkan tidak adanya perbedaan yang bermakna $(\mathrm{p}>0,05)$

Tabel 4. Perbandingan Ketepatan Waktu Kunjungan Ulang Akseptor KB Suntik 3 Bulan pada Kedua Kelompok Penelitian Sebelum dan Sesudah Perlakuan

\begin{tabular}{|c|c|c|c|c|c|}
\hline \multirow{2}{*}{\multicolumn{2}{|c|}{ Kunjungan Ulang }} & \multicolumn{3}{|c|}{ Kelompok } & \multirow{3}{*}{ Nilai $\mathbf{p}$} \\
\hline & & & $\operatorname{uan}(n=31)$ & Kontrol(n= 31) & \\
\hline Pre-test & Tepat waktu & 12 & 10 & 23 & \\
\hline Post-test & $\begin{array}{l}\text { Tepat waktu } \\
\text { Tidak tepat waktu }\end{array}$ & 29 & 2 & 30 & \\
\hline$\%$ Pening & n Ketepatan Waktu & 17 & $54,8 \%)$ & $7 \quad(22,6 \%)$ & $0,009^{*}$ \\
\hline
\end{tabular}

Keterangan: *) Uji Chi Square.

Penerapan booklet kunjungan meningkatkan persentase ketepatan waktu akseptor dalam melakukan kunjungan ulang $(\mathrm{p}<0,05)$.

\section{Diskusi}

Penerapan booklet kunjungan merupakan cara untuk menyampaikan informasi tentang $\mathrm{KB}$ suntik 3 bulan melalui media atau alat bantu berupa booklet. Informasi yang disajikan di dalam booklet bersifat spesifik sehingga dapat mempermudah akseptor KB suntik 3 bulan untuk menerima pesan atau suatu informasi dengan tujuan untuk meningkatkan pengetahuan tentang isu-isu kesehatan.Booklet digunakan sebagai media alternatif untuk dipelajari pada setiap saat bila seseorang menghendakinya. ${ }^{15}$

Penerapan booklet kunjungan ini cenderung lebih meningkatkan pengetahuan dan sikap akseptor KB suntik 3 bulan. Namun, tidak tampak adanya perbedaan yang bermakna jika dibandingkan dengan penyampaian informasi secara lisan ( $>00,05)$.Penerapan booklet kunjungan ini mampu meningkatkan persentase ketepatan waktu akseptor dalam melakukan kunjungan ulang $(p<0,05)$.Hasil penelitian ini sejalan dengan penelitian terdahulu yang menyatakan bahwa tidak terdapat perbedaan peningkatan yang bermakna pada pengetahuan responden yang diberikan pendidikan kesehatan metode ceramah dibandingkan dengan booklet dengan nilai $\mathrm{p}=0,439$, tidak terdapat perbedaan peningkatan yang bermakna pada sikap responden yang diberikan pendidikan kesehatan tentang pencegahan kanker payudara dengan pemeriksaan payudara sendiri (SADARI) antara metode ceramah dibandingkan dengan booklet dengan nilai $\mathrm{p}=0,714$, dan terdapat perbedaan bermakna perilaku pencegahan kanker payudara 
antara responden yang diberi pendidikan kesehatan tentang pemeriksaan payudara sendiri melalui media bookletdibandingkan dengan metode ceramah dengan nilai $\mathrm{p}=0,003 .{ }^{16}$

Setiap individu mempunyai kapasitas memori yang berbeda-beda. Salah satu faktor dalam meningkatkan kapasitas ini adalah pengetahuan. Semakin besar pengetahuan individu terhadap suatu informasi, semakin baik pengorganisasian dan penyerapan informasi tersebut bagi dirinya.Kepatuhan seseorang melakukan penyuntikan ulang dipengaruhi oleh pengetahuan tentang kontrasepsi suntik. ${ }^{17}$

Menurut Brunner, pada dasarnya pengetahuan setiap individu bervariasi dan akan terus bertambah sesuai dengan pengalaman. Suatu informasi yang baru diperoleh dapat menjadi pengganti informasi sebelumnya atau sebagai penyempurna informasi sebelumnya. ${ }^{18}$ Salah satu strategi agar penyampaian informasi dapat lebih efisien dalam meningkatkan kapasitas memori kerja ialah pengulangan. Pengulangan merupakan proses mempertahankan informasi dalam memori kerja secara berkali-kali. Pengulangan berperan penting dalam pembelajaran. Semakin lama informasi bertahan dalam memori kerja, semakin besar kemungkinan informasi dipindahkan ke memori jangka panjang (long-term memory).Para ahli menyatakan bahwa suatu informasi dapat tersimpan lama di dalam memori pendengar dalam jangka waktu lama jika dilakukan berkali-kali. ${ }^{13}$

Pada penelitian ini, praktik kunjungan ulang menurut data awal kelompok kontrol lebih banyak tepat waktu dari pada kelompok perlakuan.Hal ini berpengaruh terhadap kemampuan penyerapan informasi oleh responden dari intervensi yang berikan.Bagi kelompok perlakuan yang mayoritas kunjungan ulang sebelumnya tidak tepat waktu, informasi dapat menjadi sesuatu hal yang baru dipahami.Sehingga jika tidak dilakukan pengulangan maka informasi tersebut dapat terlupakan.Sedangkan bagi kelompok kontrol yang mayoritas kunjungan ulang sebelumnya tepat waktu, informasi menjadi sesuatu hal yang semakin mematangkan pengetahuan mereka sebelumnya.Berdasarkan hal ini, peningkatan skor pengetahuan pada kedua kelompok menjadi tidak berbeda.

Para ahli menyatakan bahwa penilaian sikap yang dilakukan secara berulang dapat menunjukkan sikap yang menetap dan menuju pada tindakan yang baik. ${ }^{12}$ Pada penelitian ini, praktik kunjungan ulang pre pada kelompok kontrol hampir seluruhnya tepat waktu.Praktik seperti ini dapat terjadi oleh karena adanya sikap positif pada dirinya.Informasi lisan yang diberikan pada kelompok ini tidak meningkatkan skor sikap secara signifikan.Berbeda dengan kelompok perlakuan, praktik kunjungan ulang pre pada kelompok ini hampir seluruhnya tidak tepat waktu.Rangsangan berupa media booklet kunjungan yang diberikan mampu meningkatkan sikap pada kelompok ini.Sehingga, ketika dilakukan perbandingan tidak tampak adanya perbedaan skor peningkatan sikap akibat dari diterapkan booklet kunjungan ini.

Informasiyang diperoleh mampu meningkatkanpengetahuandanmenumbuhkan kesadaranpengguna kontrasepsi.Salah satu penelitian mengatakan bahwa wanita yangmemperolehinformasi lebih memungkinkan untukmenggunakan alat kontrasepsisecara efektifdibandingkan dengan wanita yang tidak memperoleh informasi. ${ }^{19}$ Booklet kunjungan mampu meningkatkan jumlah akseptor yang menjadikan mereka sebagai pengguna KB suntik 3 bulan yang tepat yaitu menggunakan KB suntik 3 bulan secara berkesinambungan.Hal ini disebabkan karena adanya perubahan pada pengetahuan. Peningkatan pengetahuan ini menimbulkan adanya proses upaya bagi akseptor untuk mampu menerapkan pengetahuannya dalam kehidupan sehari-hari yaitu sebagai pengguna yang efektif. Berdasarkan hal tersebut, tampak pada hasil akhir praktik kunjungan ulang akseptor meningkat menjadi tepat waktu.

Disamping itu, ketepatan waktu akseptor juga didukung oleh kuatnya daya ingat akseptor akan jadwal kunjungan ulang. Daya ingat akseptor dibangun oleh adanya penandaan pada penanggalan kunjungan ulang yang dituangkan dalam bentuk kalender pada booklet kunjungan ini. Penandaan tanggal secara visual dan verbal yang dilakukan oleh peneliti mampu menarik perhatian sehingga akseptor semakin ingat akan kunjungan ulangnya. ${ }^{13}$

Dapat disimpulkan bahwa pengetahuan dan sikap akseptor $\mathrm{KB}$ suntik 3 bulan antara yang diterapkan booklet kunjungan dengan yang tanpa diterapkan booklet kunjungan tidak berbeda, namunpenerapan booklet kunjungan ini mampu meningkatkan persentase ketepatan waktu akseptor KB suntik 3 bulan dalam melakukan kunjungan ulang.

65|IJEMC, Volume 3 No. 1, Maret 2016 
Dengan demikian, pemanfaatan booklet kunjungan oleh akseptor KB suntik 3 bulan perlu dilakukan monitoring guna memperoleh hasil yang maksimal.Begitu pula pada pengamatan praktik kunjungan ulang hendaknya ditingkatkan

\section{Daftar Pustaka}

1. Peter S.Millennium Development Goals. Meningkatkan kesehatan ibu. Indonesia. 2008. p.20-2.

2. Kementerian Perencanaan Pembangunan Nasional/ Badan Perencanaan Pembangunan Nasional (BAPPENAS). Laporan Pencapaian Tujuan Pembangunan Milenium di Indonesia 2011. Meningkatkan Kesehatan Ibu. p. 53-66.

3. Badan Pusat Statistik BKKBN, Kementerian Kesehatan. Survei Demografi dan Kesehatan Indonesia Laporan Pendahuluan Jakarta, Indonesia 2012. p. 14-21.

4. Elizabeth Tolley SL, Kafa L, and Cummings S. The impact of menstrual side effects on contraceptive discontinuation: findings from a longitudinal study in Cairo, Egypt. International Family Planning Perspectives. 2005; 31(1):15-23.

5. Hubacher DNG, Gonzalez B, Taylor D. Factors affecting continuation rates of DMPA. Original Research Articles. 1999; 60(6):345-51.

6. Paul C DCGS, Williams S. Depot medroxyprogesterone acetate: patterns of use and reasons for discontinuation contraception. 1997; 56(4):209-14.

7. John M. Westfall DSMaLB. Continuation rates among injectable contraceptive users. Family Planning Perspectives 1996; 28(6):275-7.

8. Baumgartner JN CM, Mlobeli RD, Otterness C, Myer L, Janowitz B, Stanback $\mathrm{J}$ et al. Timeliness of contraceptive reinjections in South Africa And its relation to unintentional discontinuation. International Family Planning Perspectives. 2007; 2(33):66-74.

9. Sangi-Haghpeykar H ANPr, Moseley DC, Bateman L, Reid ED. Characteristics of injectable contraceptive users in a low-income population in Texas. Family Planning Perspectives. 1995; 27(5):208-11. dan dilakukan pada akseptor dengan kunjungan ulang yang tidak tepat waktu guna mencapai perubahan pengetahuan, sikap, dan praktik kunjungan ulang yang benar-benar sudah berkembang dengan baik.

10. Hampton M. A process model of Depo-Provera use in Canadian Women. Health Care for Women International. 2003; 24:193-208.

11. Bigrigg A EM, Gbolade B, Newton J, Pollard L, Szarewski A, Thomas C, Walling M. Depo Provera. Position paper on clinical use, effectiveness and side effects. Br J Fam Plann. 2000; 2(25):69-76.

12. Novita N YF. Promosi Kesehatan dalam pelayanan kebidanan. Prinsip perubahan perilaku. Jakarta: Salemba Medika; 2013. p. 73-101.

13. Slavin RE. Teori pendidikan: teori dan praktik. Kesembilan ed. Jakarta: Indeks; 2011. p. 215-71.

14. Notoatmodjo S. Pendidikan dan perilaku kesehatan. Jakarta: Rineka Cipta; 2003. p. 56-84.

15. Maulana HDJ. Promosi kesehatan. Jakarta: EGC; 2009.

16. Damayanti FN LM, Anggraini NN. Perbedaan pengaruh pendidikan kesehatan dengan metode ceramah dibandingkan booklet terhadap pengetahuan, sikap dan perilaku pencegahan kanker payudara $(\mathrm{Ca}$ Mammae) pada wanita usia subur dengan pemeriksaan sadari di Puskesmas Kedungmundu Kota Semarang Pros Sem Nas Entrepreneurship. 2014: 218-27.

17. Pujiati N. Hubungan tingkat pengetahuan tentang kontrasepsi suntik dengan kepatuhan jadwal penyuntikan ulang di Rumah Bersalin An Nissa Surakarta. 2009.

18. Mubarak WI. Promosi Kesehatan untuk kebidanan. Jakarta: Salemba Medika; 2011.

19. Lauria L SD, Spinelli A, Bonciani M, Grandolfo ME. The effect of contraceptive counselling in the pre and post-natal period on contraceptive use at three months after delivery among Italian and immigrant women. 2014; 50(1):54-61. 